\title{
US scientists slow in grasping potential of supercomputers
}

\section{Washington}

DESPITE a late start, Japanese industry is buying more supercomputers than its US counterparts. And although US supercomputer manufacturers may still have a technological lead, US industry is not capitalizing on the advantages offered. Those themes lay behind a symposium on supercomputers organized in Washington last week by the National Research Council.

The precursors of today's fastest machines appeared in the early 1970s, and the first Cray-1 was delivered in 1976. But until recently, almost all the supercomputing capability of the United States resided in a few federal laboratories, and was largely reserved for classified defence work. Only a few academic researchers were persistent enough to obtain small allotments of supercomputing time.

As well as slowing the development of general applications and software for supercomputers, a more far-reaching effect, according to Jack Worlton of Los Alamos National Laboratory, was that for 15 years science and engineering students passed through universities ignorant of what supercomputers could do. Many of those students are now senior academic and industrial scientists, and are still slow to grasp the potential of modern computers.

Three years ago, the National Science Foundation (NSF) began its support of five national supercomputing centres. According to Larry Smarr, a pioneer of numerical astrophysics and now director of the National Center for Supercomputing Applications (NSAC) in Urbana, Illinois, a key aim is to educate scientists in the use of supercomputers. Smarr has also drawn industry into NSAC, attracting as much as $\$ 1$ million additional yearly funding from partners such as Eastman Kodak and Amoco.

Surprisingly, representatives from Kodak, Apple Computer and Abbott Laboratories, a pharmaceutical company, all agreed that it is generally easier to persuade management of the need for supercomputers than it is scientists. But by demonstrating how to simulate plastic injection moulding, heat generation in printed circuits or drug design by computational chemistry, NSAC scientists have been able to convince their colleagues in industry that supercomputers can speed and simplify product development

To take full advantage of what supercomputers can offer, users must be able to tell machine designers what they need. Steve Chen, until recently chief designer at Cray and now president of his own company, argued that the simple pursuit of computational speed was only a small part of supercomputer development. Compromises must be made, for example, between memory size and access speed, between speed of arithmetic operation and of data movement, between small numbers of large processors and vice versa; in all these choices, the type of computing job to be done influences the compromise to be made.

According to Smarr and Chen, Japanese technology trails American by perhaps two years, perhaps a few months. US computer science holds a definite advantage in novel architecture (such as the massively parallel Connection Machine), but such innovations are a long way from widespread commercial applicability. The hardest problems facing supercomputer designers now are the relatively mundane constraints of materials science - electron conduction on nanosecond timescales and heat dissipation, in particular - and these are areas in which the Japanese researchers have proven ability. A feeling emerged from the meeting that if the United States loses the lead it now possesses, much of the blame will rest on consumer indifference. David Lindley

\section{Row over White House moves to ban fetal tissue research}

\section{Washington}

A PRESIDENTIAL order that would have effectively banned the use of human fetal tissue for research or transplantation has been postponed, but not before causing considerable consternation among scientists and ethicists preparing to discuss such

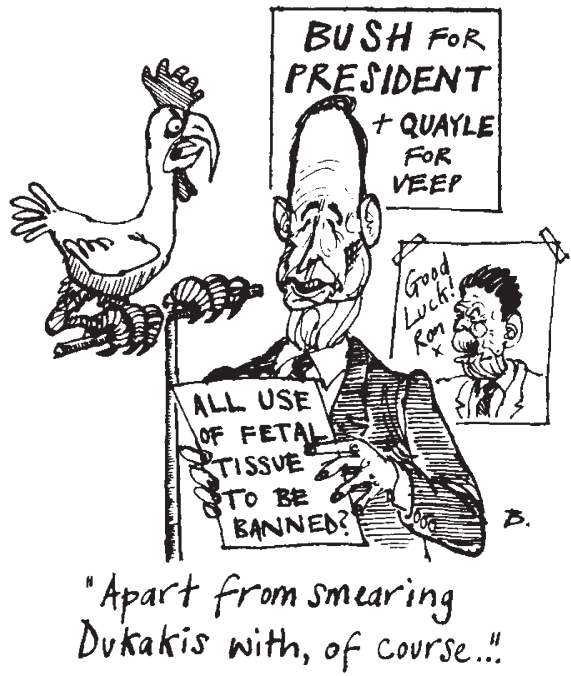

issues in Bethesda next week at the request of the Reagan administration.

The order originated in the office of Gary Bauer, assistant to the president for policy development. In addition to banning fetal tissue research and removal of fetal organs not intended to benefit directly the fetus involved, it would also ban the use of such organs taken from a fetus recovered from an induced abortion. The edict would define life as beginning with fertilization, precluding research on certain contraceptives, such as the intrauterine device, that interfere with implantation rather than fertilization.

In a letter dated 2 September, Bauer wrote to Otis Bowen, Secretary of Health and Human Services (HHS), informing him that the order would be put through the White House clearance process "as soon as possible", and asking for comments by 9 September. As the letter was sent on Friday, and the following Monday was a national holiday, HHS had only three days to prepare its response. A copy of the order was leaked to the news media and on Friday, 9 September the White House insisted that no change in policy was imminent.

The preemptory nature of the executive order was particularly upsetting to those planning to attend a meeting this week of the Human Fetal Tissue Transplantation Research Consultant Panel at the National Institutes of Health (NIH). The panel was formed last July at the request of Robert Windom, Assistant Secretary for Health, who placed a temporary ban on all federally funded research involving transplantation of human fetal tissue obtained from induced abortion. The panel is to discuss the scientific and ethical issues relating to such research and prepare its recommendations for Windom, who will then decide whether to lift the ban. Those associated with the meeting contended that there would be little point in holding it if the presidential order was implemented as written.

The timing of the order led many to conclude that the motivation was political rather than scientific or ethical. Lately, the Reagan Administration has shown an interest in opening up the debate over controversial topics relating to human life. In addition to this week's NIH meeting, the administration also this week published in the Federal Register a proposed new charter for the HHS Ethics Advisory Board. The board has not existed for eight years, and it must approve certain research projects, notably in vitro fertilization, before such projects can receive federal funds. These topics have already come up in the presidential campaign, and are likely to help divide the positions of the two candidates.
Joseph Palca 